\title{
PRZYKŁADY NAPRAW I RENOWACJI POSADZEK PRZEMYSŁOWYCH
}

\author{
Barbara Ksit ${ }^{1}$, Anna Szymczak-Graczyk ${ }^{2 \square}$ \\ ${ }^{1}$ Wydział Budownictwa i Inżynierii Środowiska, Politechnika Poznańska, Poznań \\ ${ }^{2}$ Wydział Inżynierii Środowiska i Gospodarki Przestrzennej, Uniwersytet Przyrodniczy w Poznaniu, Poznań
}

\begin{abstract}
STRESZCZENIE
Uszkodzenia posadzek betonowych dotyczą głównie ich wierzchniej warstwy i można je podzielić na kilka grup: pęknięcia, wyłupania, odspojenia, łuszczenie i zmiana równości. System naprawczy dobiera się zależnie od skali zniszczenia i jego położenia (inaczej będzie wyglądała naprawa pęknięcia posadzki w alejce transportowej, a inaczej przy słupie). Podstawowymi metodami naprawczymi są uzupełnienia (masą dylatacyjną, żywicą epoksydową lub masami cementowymi) oraz szlifowanie i polerowanie. Ważne jest właściwe zaprojektowanie wszystkich warstw posadzki przemysłowej.
\end{abstract}

Słowa kluczowe: posadzka przemysłowa, naprawa, renowacja, płyty betonowe

\section{WSTĘP}

Posadzki przemysłowe to istotny element obiektów przemysłowych, produkcyjnych oraz magazynowych. Wybór odpowiedniego rozwiązania, rygorystyczne przestrzeganie wytycznych wykonania mają ogromny wpływ na trwałość warstw podłogowych, a tym samym na komfortowe użytkowanie i minimalizowanie ewentualnych późniejszych problemów. Standardowo posadzki przemysłowe projektuje się na zdefiniowany okres użytkowania (nieprzerwanej pracy zakładu) wynoszący 25 lat (Małasiewicz i Tejchman, 2006). W podanym czasie podłoga powinna spełniać wymogi trwałości i dotyczy to wszystkich warstw zarówno konstrukcyjnych, jak i warstwy wierzchniej, którą najczęściej wykonuje się z użyciem suchej posypki utwardzającej. Opisywane elementy muszą także spełniać wymagania odnośnie trwałości, nośności, płaskości (równości powierzchni) oraz odporności fizykochemicznej. Wykonywanie posadzek przemysłowych powinno być przeprowadzane zgodnie z dokumentacją projektową.
W praktyce niestety często warstwy podłogowe są wykonywane na podstawie szczątkowych wytycznych zawartych $\mathrm{w}$ projektach budowlanych i wykonawczych. Najczęściej w projektach znajdują się jedynie rzuty i przekroje zawierające rodzaje wykończenia posadzek i ogólny opis. W dokumentacjach projektowych bardzo często pomijane są informacje dotyczące parametrów poszczególnych warstw podłogi oraz wytycznych do ich wykonania, użytkowania i konserwacji (BS 8204-2:2002; Concrete Society, 2014). $\mathrm{W}$ projektach wykonawczych brakuje informacji o dylatacjach i szczegółach wykończeniowych. Posadzki przeznaczone jedynie na użytek ludzi często są traktowane jako element wykończeniowy, stąd sporządzenie ich dokumentacji projektowej spoczywa na architektach. Jeśli projektowana posadzka ma być wykonana $\mathrm{np}$. w hali produkcyjnej, wymaga dokładnej analizy obliczeniowej, która określi parametry statyczno-wytrzymałościowe i powinna być wykonana przez projektanta konstruktora. Brak wytycznych projektowych lub zmiana sposobu użytkowania posadzki już w trakcie eksploatacji mogą wywołać niepożądane skutki,

凶anna.szymczak-graczyk@up.poznan.pl 
np. powstanie rys lub pęknięć. Każde uszkodzenie płyty posadzki, a tym samym konieczność naprawy, powoduje przestoje w użytkowanych obiektach (na czas naprawy zamykane zostają uszkodzone obszary podłogi). Z powodu tych przestojów inwestor ponosi duże straty finansowe. Dla podkreślenia ważności tego elementu konstrukcyjnego warto zauważyć, że koszt prawidłowego wykonania posadzki przemysłowej w obiekcie to, w zależności od jej skomplikowania, około 20-25\% nakładu finansowego przeznaczonego na jego budowę.

\section{PODZIAŁ I DOBÓR ROZWIĄZANIA}

Współcześnie wykonuje się dwa podstawowe typy posadzek: posadzki spoinowe oraz posadzki bezspoinowe. Na rysunku 1 pokazano przekrój przez standardową posadzkę przemysłową.

Zależnie od możliwości wykonania danej hali, rodzaju podłoża oraz typu procesów produkcyjnych mających odbywać się w danym obiekcie dobiera się odpowiedni typ konstrukcji płyty posadzkowej.

Posadzki spoinowe (nacięciowe) wykonuje się w:

- halach o skomplikowanym rzucie (zarówno ścian zewnętrznych, jak i wewnętrznych),

- przypadku konstrukcji nieutwardzanej, przy której wykonuje się kolejne warstwy, np. posadzki żywiczne, jastrychy, układa płytki lub wykładziny,

- miejscach, gdzie podłoga będzie bardzo mocno obciążona w całości lub punktowo, w których powstawać będą duże naprężenia,

- miejscach, gdzie nie będzie odbywał się ciężki transport (szczególnie na twardych kołach, bo skutkuje to wykruszaniem się krawędzi dylatacji nacinanych),

- sytuacji małego budżetu, ponieważ posadzki nacinane są zwykle tańsze od bezdylatacyjnych.

Płyty bezspoinowe (beznacięciowe) wykonuje się w (Osińska i Ksit, 2017):

- wielkopowierzchniowych halach magazynowych, logistycznych,

- halach o nieskomplikowanym rzucie,

- halach, gdzie ustawianych jest wiele rzędów regałów, ponieważ poprawny przebieg dylatacji konstrukcyjnych wyklucza możliwość ustawienia stopy regału na dylatacji roboczej (konstrukcyjnej) posadzki lub w jej najbliższym sąsiedztwie,

- halach, gdzie planowane jest tzw. wysokie składowanie (regały magazynowe o możliwościach składowania na wysokości powyżej $6 \mathrm{~m}$ ) oraz gdzie wózki transportowe poruszają się w wąskich torach jazdy, tj. w alejkach między regałami (rozwiązanie bezdylatacyjne zapobiega przed każdorazowym „chybotaniem się” wózka w momencie przejazdu przez szczelinę dylatacji ciętej),

- przypadkach, gdy pozwalają na to warunki gruntowo-wodne,

- halach niezlokalizowanych na terenach szkód górniczych.

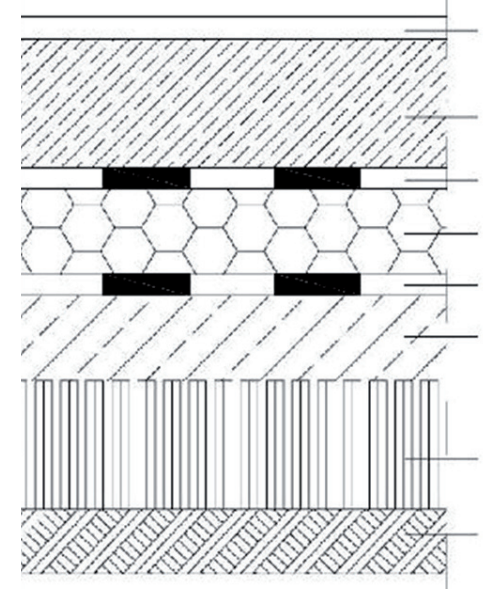

warstwa wierzchnia

top layer

warstwa konstrukcyjna (np. płyta betonowa)

constraction layer (e.g concrete slab)

warstwa poślizgowa

sliding layer

izolacja termiczna

thermal isolation

izolacja przeciwwilgociowa

anti-moisture insulation

warstwa wyrównawcza

leveling layer

\section{podbudowa}

foundation

podłoże gruntowe subsoil

Rys. 1. Przekrój przez standardową posadzkę przemysłową z termoizolacją (Małasiewicz i Tejchman, 2006)

Fig. 1. Section of standard industrial floor with thermal insulation (Małasiewicz \& Tejchman, 2006) 


\section{RODZAJE USZKODZEŃ I ZNISZCZEŃ PŁYT POSADZKOWYCH}

Posadzki przemysłowe są z reguły najbardziej wytężonym i narażonym na negatywne wpływy eksploatacji elementem każdej hali zarówno produkcyjnej, jak i magazynowej. W celu zwiększenia wytrzymałości betonu stosowane są włókna stalowe, węglowe, z tworzyw sztucznych, szklane oraz pochodzenia organicznego. Różnorodność materiałów, z których wykonywane są włókna, wpływa na dużą odmienność właściwości podłóg betonowych. Przykładowe porównanie parametrów włókien przedstawiono w tabeli 1 .

Doświadczenia prowadzone przez firmę ArcelorMittal potwierdzają, że im bardziej smukłe włókno, tym mniej go można dozować, aby nie stracić na końcowej nośności płyty. Niestety włókna o bardzo dużej smukłości dostarczają wiele problemów wykonawczych takich jak trudności przy zacieraniu posadzki (włókna wychodzą na powierzchnię płyty w ilości większej niż dopuszcza norma). Alternatywnym sposobem zbrojenia posadzek są włókna polimerowe. Dla tych samych parametrów podłoga $\mathrm{z}$ włóknami stalowymi osiąga grubość $18 \mathrm{~cm}$, a zużycie tych włókien wynosi $25 \mathrm{~kg} \cdot \mathrm{m}^{-3}$, z włóknami polimerowymi jej grubość wynosi $15 \mathrm{~cm}$, a zużycie tych włókien wynosi $1,8 \mathrm{~kg} \cdot \mathrm{m}^{-3}$. Coraz częściej spotyka się też rozwiązania „hybrydowe" - projektanci łączą ze sobą zbrojenie tradycyjne i zbrojenie włóknami w zależności od indywidualnych potrzeb konstrukcji. Kombinacja siatek stalowych i włókna stalowego pozwala na uzyskanie większej sztywność płyty, redukowanie spękań i mikrospękań.

Chcąc uniknąć uszkodzeń posadzek w miejscach, w których występować będą zwiększone naprężenia (np. przy narożach wklęsłych, słupach, narożnikach wydzielonych pomieszczeń, w strefach wjazdów czy okolicach doków rozładunkowych), należy wykonywać dozbrojenie w postaci prętów lub siatek zgrzewanych ze stali gatunku B500SP (A-III).

Tabela 1. Zestawienie parametrów różnego rodzaju włókien dodawanych do betonu (Osińska, 2017)

Table 1. Parameters list of various types of fibers added to concrete (Osińska, 2017)

\begin{tabular}{|c|c|c|c|c|}
\hline $\begin{array}{l}\text { Parametr } \\
\text { Parameter }\end{array}$ & $\begin{array}{l}\text { Jednostka } \\
\text { Unit }\end{array}$ & $\begin{array}{l}\text { Włókno stalowe } \\
\text { Steel fiber }\end{array}$ & $\begin{array}{l}\text { Włókno polimerowe } \\
\text { Polimer fiber }\end{array}$ & $\begin{array}{c}\text { Włókno bazaltowe } \\
\text { Basalt fiber }\end{array}$ \\
\hline $\begin{array}{l}\text { Gęstość } \\
\text { Density }\end{array}$ & $\mathrm{t} \cdot \mathrm{mm}^{-3}$ & 7,8 & $0,9-1,4$ & $1,7-2,65$ \\
\hline $\begin{array}{l}\text { Długość } \\
\text { Length }\end{array}$ & $\mathrm{mm}$ & $8-60$ & $6-54$ & $25-54$ \\
\hline $\begin{array}{l}\text { Średnica } \\
\text { Diameter }\end{array}$ & $\mu$ & $20-40$ & $12-34$ & $12-18$ \\
\hline $\begin{array}{l}\text { Moduł Younga } \\
\text { Young's modulus }\end{array}$ & $\mathrm{GPa}$ & $190-210$ & $35-40$ & $70-90$ \\
\hline $\begin{array}{l}\text { Wytrzymałość na rozciąganie } \\
\text { Tensile strength }\end{array}$ & $\mathrm{MPa}$ & $550-1100$ & $480-1320$ & $700-1680$ \\
\hline $\begin{array}{l}\text { Wydłużenie przy zerwaniu } \\
\text { Elongation at break }\end{array}$ & $\%$ & - & $2,0-4,0$ & $0,5-1,6$ \\
\hline $\begin{array}{l}\text { Odporność na korozję } \\
\text { Corrosion resistance }\end{array}$ & - & $\begin{array}{c}\text { nie } \\
\text { no }\end{array}$ & $\begin{array}{l}\text { tak } \\
\text { yes }\end{array}$ & $\begin{array}{l}\text { tak } \\
\text { yes }\end{array}$ \\
\hline $\begin{array}{l}\text { Odporność ogniowa } \\
\text { Fire resistance }\end{array}$ & ${ }^{\circ} \mathrm{C}$ & $\begin{array}{c}\text { do } 1600 \\
\text { up to } 1,600\end{array}$ & $\begin{array}{l}\text { do } 160-165 \\
\text { up to } 160-165\end{array}$ & $\begin{array}{l}\text { do } 1650 \\
\text { up to } 1,650\end{array}$ \\
\hline $\begin{array}{l}\text { Temperatura robocza } \\
\text { Working temperature } \\
\end{array}$ & ${ }^{\circ} \mathrm{C}$ & $\begin{array}{c}\text { od }-50 \text { do }+300 \\
\text { from }-50 \text { to }+300\end{array}$ & $\begin{array}{l}\text { od }-20 \text { do }+120 \\
\text { from }-20 \text { to }+120\end{array}$ & $\begin{array}{l}\text { od }-260 \text { do }+750 \\
\text { from }-260 \text { to }+750\end{array}$ \\
\hline $\begin{array}{l}\text { Twardość } \\
\text { Hardness }\end{array}$ & $\begin{array}{c}\text { skala Mohsa } \\
\text { Mohs scale }\end{array}$ & 9 & $1-3$ & 8,5 \\
\hline $\begin{array}{l}\text { Przyczepność do betonu } \\
\text { Adhesion to concrete }\end{array}$ & - & $\begin{array}{l}\text { bardzo dobra } \\
\text { very good }\end{array}$ & $\begin{array}{l}\text { słaba } \\
\text { poor }\end{array}$ & $\begin{array}{c}\text { bardzo dobra } \\
\text { very good }\end{array}$ \\
\hline
\end{tabular}


Na poprawną pracę zaprojektowanej posadzki bardzo duży wpływ mają także parametry podbudowy. Najważniejszymi parametrami są moduł odkształcenia wtórnego podłoża $\left(E_{v 2}\right)$ oraz stosunek tego modułu do modułu pierwotnego odkształcenia $\left(E_{v 2} / E_{v 1}\right)$. Im lepiej jest przygotowana wielowarstwowa podbudowa i jej moduł odkształcenia wtórnego ma większa wartość, tym większe obciążenie przenieść może płyta. I tak np. płyta o grubości $18 \mathrm{~cm}$, zbrojona włóknami stalowymi w ilości $25 \mathrm{~kg} \cdot \mathrm{m}^{-3}$, przyjmowana dla uproszczonego schematu obliczeniowego jako ułożona na jednej warstwie podbudowy o wartościach $E_{v 2}$ $=150 \mathrm{MPa}$ oraz $E_{v 2} / E_{v 1}=2,20$ przeniesie $\mathrm{w}$ rzeczywistości obciążenie mniejsze niż otrzymane $\mathrm{z}$ obliczeń. Uwzględniając podłoże wielowarstwowe o parametrach wynoszących $E_{v 2}=90 \mathrm{MPa}$ oraz $E_{v 2} / E_{v 1}$ $=2,50$, otrzyma się rzeczywista wartość obciążenia, jaką może przenieść płyta (Ryżyński i Karczewski, 2014). Nie uwzględnienie w obliczeniach warstwowości podłoża powoduje przyjmowanie zawyżonych wartości modułu reakcji podłoża, co może prowadzić do przyjęcia zbyt małej ilości zbrojenia, co skutkuje zarysowaniem posadzki lub jej osiadaniem (Deręgowska i Szymczak-Graczyk, 2017).

Błędnie wykonana posadzka przemysłowa, konstrukcyjnie i technologicznie niedopasowana do swojej funkcji może obniżać wydajność zakładu produkcyjnego. Podstawowe przyczyny uszkodzeń podłóg przemysłowych można podzielić na: konstrukcyjne, materiałowe, technologiczne, eksploatacyjne (Osińska i Ksit, 2017).

W literaturze przedmiotu (Małasiewicz i Tejchman, 2006; Tehrani, 2008; Hajduk, 2018) definiowane są cztery główne mechanizmy niszczące: biologiczny (np. bakterie lub porosty), chemiczny (np. kwasy lub oleje), fizyczny (np. wietrzenie), fizykochemiczny (np. opady deszczu).

Każdy mechanizm inaczej wpływa na proces degradacji betonu, najczęściej występuje równocześnie kilka czynników niszczących, co powoduje dodatkowe procesy degradacyjne $\mathrm{w}$ warstwach konstrukcyjnych. Fizyczne i fizykochemiczne mechanizmy niszczenia betonu polegają na pogorszeniu jego parametrów, w tym głównie wytrzymałości w wyniku reakcji hydrofobizacji (proces mający na celu zapobieganie zawilgoceniu i biodegradacji) i zatrzymania hydratacji cemen- tu (pełny proces zachodzi w momencie, gdy zawartość wody waha się w przedziale $20-25 \%$ w stosunku do zawartości cementu). Długotrwale użytkowane płyty powinny być poddawane odpowiednim procesom renowacyjnym lub naprawczym, aby uchronić zarówno inwestora przed stratami związanymi $\mathrm{z} n \mathrm{np}$. przerwana komunikacją w hali, jak i problemem wypadkowości wśród pracowników. Proces degradacyjny bardzo często rozwija się lawinowo, co niestety często skutkuje koniecznością całkowitej renowacji lub nawet wymiany posadzki przemysłowej. $\mathrm{Z}$ tego powodu wykonawcy posadzek sugerują, aby naprawom (lub chociaż ocenie wykonywanej przez specjalistę budowlanego) poddawać uszkodzenia zaraz po ich wykryciu. Większość problemów dotyczy głównie wierzchniej części płyty posadzkowej, czyli warstwy mineralnej (posypki utwardzającej oraz warstwy impregnującej).

Głównymi problemami z wierzchnią warstwą posadzki są przypowierzchniowe pęknięcia i zarysowania, miejscowe wykruszenia i ubytki, odrywające się powłoki (np. łuszczący się impregnat akrylowy lub odspojona i złuszczona warstwa żywiczna), pylenie, rozmiękanie betonu, wykruszenia dylatacji (szczególnie nacinanych), zmiany równości posadzek w czasie, odspojenia masy dylatacyjnej (Jasiczak, 2001; Fidali, 2010).

\section{PRZYKŁADOWE SPOSOBY NAPRAW}

Przypowierzchniowe pęknięcia i zarysowania nie wpływają znacząco zarówno na trwałość posadzki, jak i użytkowanie płyty podłogowej. Spękania włosowate (mikropęknięcia) są elementem naturalnym na posadzkach wykańczanych metodą maszynową. Autorzy Technical Report 34 brytyjskiego Concrete Society (2014) na podstawie przeprowadzonych analizach podali, że ten rodzaj spękań nie stanowi żadnego zagrożenia dla konstrukcji ani dla użyteczności. $\mathrm{W}$ pierwszych godzinach twardnienia betonu tworzą się mikrospękania, które powoduje tzw. skurcz plastyczny. Później powiększają się one przez wywołany skurcz karbonizacji czy skurcz wysychania. Należy zauważyć, że mikropęknięcia są bardziej widoczne w momencie zawilgocenia podłogi. W tabeli 2 podano rodzaje skurczu w świeżej mieszance betonowej.

Większość tego typu zarysowań można pozostawić bez naprawy, czyli miejsca nienarażone na degradację 
Tabela 2. Rodzaje skurczu w świeżej mieszance betonowej (Concrete Society, 2014)

Table 2. Types of shrinkage in a fresh concrete mix (Concrete Society, 2014)

\begin{tabular}{lcc}
\hline $\begin{array}{l}\text { Rodzaj skurczu } \\
\text { Type of contraction }\end{array}$ & $\begin{array}{c}\text { Przyczyna } \\
\text { Cause }\end{array}$ & $\begin{array}{c}\text { Czas występowania } \\
\text { Time of occurrence }\end{array}$ \\
\hline $\begin{array}{l}\text { Osiadanie plastyczne } \\
\text { Plastic settlement }\end{array}$ & $\begin{array}{c}\text { wpływ wody zarobowej } \\
\text { influence of mixing water }\end{array}$ & 10 min $-3 \mathrm{~h}$ \\
\hline $\begin{array}{l}\text { Skurcz plastyczny } \\
\text { Plastic shrinkage }\end{array}$ & $\begin{array}{c}\text { wczesne wysychanie } \\
\text { early drying }\end{array}$ & 30 min $-6 \mathrm{~h}$ \\
\hline $\begin{array}{l}\text { Wczesny odkształcenia termiczne } \\
\text { Early thermal deformation }\end{array}$ & $\begin{array}{c}\text { gradient temperatury } \\
\text { temperature gradient }\end{array}$ & 1 dzień $-2-3$ tygodnie \\
\hline $\begin{array}{l}\text { Długoterminowy skurcz od wysychania }-2-3 \text { weeks } \\
\text { Long-term shrinkage from drying out }\end{array}$ & $\begin{array}{c}\text { wadliwe dylatacje } \\
\text { faulty dilations }\end{array}$ & $\begin{array}{c}\text { kilka tygodni }- \text { kilkanaście miesięcy } \\
\text { several weeks }- \text { several months }\end{array}$ \\
\hline
\end{tabular}

przez np. koła wózków transportowych oraz miejsca nieistotne dla pracy konstrukcji i nośności płyty. Producenci materiałów wykończeniowych na posadzki zalecają jednak miejsca te uszczelnić masą dylatacyjną. Przeprowadzając w ten sposób naprawę, pozwala się szczelinie dalej pracować, a sama płyta ma możliwość odciążyć się od skumulowanego w tym miejscu naprężenia.

Rysy występujące w ciągach komunikacyjnych lub w miejscach, gdzie konieczne jest przenoszenie naprężeń, należy zszyć lub przeprowadzić iniekcję. Uszczelnienia masą dylatacyjną przeprowadza się standardowymi materiałami, które stosuje się do wypełniania planowanych nacięć skurczowych. Są to materiały bardzo elastyczne, które pozwalają płytom betonowym pracować (kurczyć się lub rozszerzać zależnie od panujących warunków w hali). Materiały te dobiera się najczęściej w zależności od warunków, jakie będą panowały w obiekcie, oraz od szerokości szczelin przeznaczonych do uzupełnienia. Pęknięcia przeznaczone do zszycia powinny być odpowiednio przygotowane, rozfazowane i oczyszczone z pyłu. Pręty „zszywające” (koniecznie z pręta żebrowanego w celu maksymalizacji przyczepności do masy naprawczej) powinny być zatopione na tyle głęboko, aby siły panujące w posadzce ich nie wyrwały i nie spowodowały dalszych uszkodzeń. Warto pamiętać, że środek naprawczy powinien być odpowiedniej twardości. W takich przypadkach doskonale sprawdzają się cementowe masy naprawcze oraz twarde żywice. Ostatnim, najmniej wymagającym sposobem naprawy pęknięcia jest iniekcja, czyli wtło- czenie mieszanki naprawczej bezpośrednio do bardzo wąskiej szczeliny z użyciem np. strzykawki. Jednym z popularnych materiałów do przeprowadzania iniekcji w betonie jest specjalna mieszanka cementów oraz dodatków uplastyczniających. Materiał ten charakteryzuje się bardzo dużym skurczem początkowym i końcowym, a jego płynna konsystencja pozwala na przeprowadzanie napraw w sposób grawitacyjny i ciśnieniowy. Do naprawy posadzek przeznaczone są również żywice iniekcyjne, które można stosować zarówno na mokre, jak i suche podłoże. Jednym z twardych materiałów naprawczych sklejających pęknięcia w sposób sztywny jest polimetakrylan metylu. Na rysunku 2 przedstawiono opisane sposoby naprawy.

Miejscowe wykruszenia i ubytki to kolejne często występujące uszkodzenia posadzek. Zależnie od ich powierzchni i głębokości można zastosować różne metody naprawcze. Jeżeli do czynienia mamy z małymi wykruszeniami lub np. ubytkami po wystającym włóknie stalowym, to dobrym rozwiązaniem jest uzupełnienie ich masą żywiczną lub mineralną; są to trwałe i sprawdzone metody powszechnie stosowane w większości obiektów. Mogą być one także stosowane do większych uszkodzeń, ale producenci systemów naprawczych zalecają odpowiednie przygotowanie rewitalizowanego ubytku. Wykonana naprawa powinna być równie wytrzymała co sama posadzka, dlatego ważna jest dużą przyczepność nowego materiału do naprawianego podłoża.

Producenci oferują wiele nowych technologii dla napraw elementów betonowych. Masy napraw- 

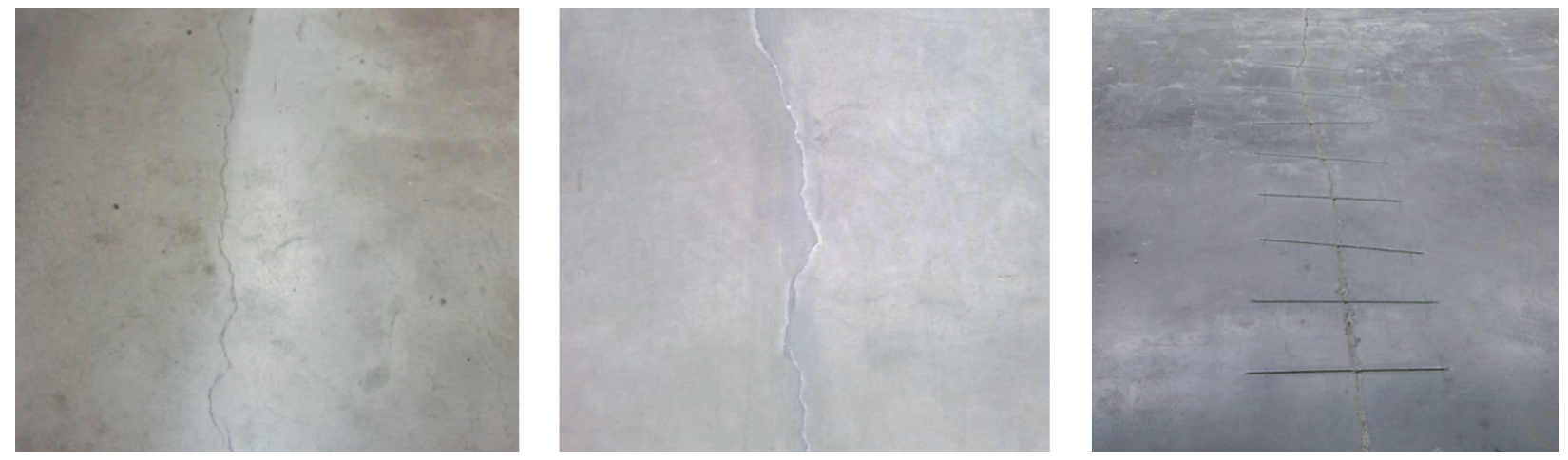

Rys. 2. Kolejno od lewej: pęknięcie pozostawione bez naprawy, wypełnione materiałem elastycznym bez frezowania krawędzi rys i zszyte (Osińska, 2017)

Fig. 2. From the left: crack left without repair, filled with elastic material without edge milling and stapled (Osińska, 2017)

cze dobiera się w zależności od wymaganej wytrzymałości oraz grubości warstwy, jaką trzeba nałożyć, aby zlicować poziom masy naprawczej z poziomem płyty posadzkowej. Przy renowacjach powierzchni uszkodzonych zaleca się stosowanie materiału, który jak najszybciej uzyskuje pełną wytrzymałość. Takim produktem jest mineralna zaprawa naprawcza, która wystarczające parametry nośności uzyskuje już po godzinie od jej ułożenia i równocześnie cechują ją mały skurcz podczas wiązania. Nie wymaga wykonania masy sczepnej przed jej nałożeniem. Oprócz mas naprawczych do tego rodzaju napraw powierzchniowych służą także żywice. Problemy z masą dylatacyjną wypełniającą szczeliny pojawiają się w kilku przypadkach: kiedy szczelina nie została odpowiednio przygotowana do wypełnienia (czyli np. nie była odpowiednio oczyszczona lub dokładnie osuszona), wypełnienie wykonano bez należytej staranności lub ruch pojazdów transportowych jest na tyle intensywny, że wyrywa masę ze szczelin. $\mathrm{Z}$ tego powodu coraz popularniejsze (szczególnie w halach magazynowych) stają się posadzki bezdylatacyjne (beznacięciowe) ograniczające konieczność wykonania dylatacji ciętych do minimum i dzięki temu niwelujące przyczyny uszkodzeń.

Następny problem to odspajające się powłoki, które powstają w posadzkach utwardzanych powierzchniowo. Zbyt wysoki poziom napowietrzenia mieszanki może spowodować odspajanie się górnej części posadzki, „odparzanie się” warstwy utwardzającej. Naj- mniej uciążliwy przypadek to odspajanie od posadzki impregnatu. Wyróżnia się dwa podstawowe rodzaje impregnacji przeprowadzanych na posadzkach:

- impregnacja przy zastosowaniu preparatu akrylowego; materiał ten tworzy delikatną folię na płycie posadzkowej bez jej wgłębnej penetracji i jego usterkowość polega na złuszczaniu się w miejscach szczególnie eksploatowanych, co wpływa na konieczność częstego ponawiania tego zabiegu,

- impregnacja przy użyciu preparatu powstającego na bazie krzemianów sodu lub litu; jest to materiał odpowiedni do pielęgnacji posadzek mocno obciążonych; środek penetruje wierzchnią warstwę płyty i doszczelnia ją; producenci materiału zalecają, aby zabieg powtarzać średnio co dwa lata, aby mieć pewność, że posadzka jest dobrze chroniona. Należy zwrócić uwagę, że impregnaty nie chronią betonu płyt przed olejami ani kwasami, które mogą doprowadzić do wielu bardzo uciążliwych uszkodzeń wymagających niekiedy głębokiej ingerencji w posadzkę.

Kolejny problem użytkowania posadzek związany jest z pyleniem. Niestety to zjawisko jest poważną niedogodnością, kiedy w hali odbywa się produkcja żywności i przebywają ludzie. Może to powodować niewłaściwa konserwacja (zarówno nieodpowiednie środki czyszczące, jak i zupełny brak dbałości o porządek), zbyt mała ścieralność płyty w stosunku do stopnia użytkowania oraz wiek posadzki. W tym przypadku sposób naprawy uzależniony jest od stopnia 
zniszczenia płyty. Każdorazowo przed podjęciem decyzji o sposobie walczenia z pyleniem należy upewnić się, jak głęboko sięgają zniszczenia, i na tej podstawie opracować metodę naprawczą. W przypadku bardzo małego zniszczenia wystarczy wyczyszczenie płyty i ponowna impregnacja, szlifowanie i polerowanie posadzki. W przypadku znacznego uszkodzenia wykonuje się frezowanie i nadlewkę wierzchniej warstwy masą cementową lub żywiczną. Powyższe metody mają na celu poprawę wytrzymałości mechanicznej górnej powierzchni posadzki oraz dodatkowo wyrównują ją. Szlifowanie posadzki polega na miejscowym jej „ścieraniu” i odsłanianiu kruszywa posypki utwardzającej lub przy głębokim szlifie nawet płyty betonowej. Polerowanie także odkrywa kruszywa, ale dodatkowo w trakcie tego procesu nanoszone są na posadzkę impregnaty, które nadają płytom połysk. Trzeci zabieg to frezowanie, czyli ścieranie wierzchniej warstwy płyty i nadanie jej bardzo dużej szorstkości, co pozwala na zastosowanie wylewek cementowych lub żywicznych. Jeżeli istnieje konieczność zabezpieczenia posadzki przed kwasami pochodzacymi np. $\mathrm{z}$ akumulatorów wózków widłowych lub przed wyciekami olejów, należy wcześniej przewidzieć wykończenie płyty powłoką żywiczną.

Poważnym problemem jest degradacja betonu. Struktura zwykłego betonu jest otwarta i substancje szkodliwe mogą z łatwością penetrować ten materiał. Niestety wpływ substancji ropopochodnych (np. benzyna, nafta, olej napędowy, opałowy, parafina, a nawet WD-40) na beton nie jest do końca rozpoznany (Concrete Society, 2014). Badania dowodzą, że zmiana wytrzymałości, a co za tym idzie trwałości, betonu zależy od substancji ingerującej (BS 8204-2:2002). W celu zabezpieczenia betonu przed negatywnym wpływem substancji degradujących należy zaprojektować beton w odpowiedniej klasie odporności na karbonatyzację (XC1-XC4), na korozję wywołaną chlorkami niepochodzącymi z wody morskiej (XD1-XD1) oraz pochodzącymi z wody morskiej (XS1-XS3), korozję spowodowaną rozmrażaniem i zamrażaniem (XF1-XF4), a także agresję chemiczną (XA1-XA3). Należy przewidzieć powłokę ochronną w postaci wykończenia warstwy wierzchniej, warstwą żywicy epoksydowej o odpowiedniej odporności, a czasem wystarczy bar- dzo starannie zaimpregnować posadzkę dobrej klasy materiałem (co częściowo zamyka pory i nie pozwala na dostawanie się czynnika agresywnego w głąb konstrukcji).

Duży wpływ na zjawisko degradacji ma także jakość wykonania podbudowy pod posadzką. Grunt i podbudowa pod posadzką powinny zostać przebadane przez geotechników, pod kątem odpowiedniej nośności. Niestety zdarzają się wypadki, gdy podbudowa nie została wykonana prawidłowo. Przy nieznacznym curlingu wystarczy posadzkę przeszlifować do równego poziomu płyt, a przy większych nierówności należy pamiętać, że pustkę pod posadzką trzeba wypełnić np. cementową masą naprawczą lub wykonać iniekcję.

\section{PODSUMOWANIE}

Niewłaściwy dobór rozwiązania konstrukcyjnego może okazać się problemem zarówno dla inwestora, jak i dla wykonawcy posadzki. Kombinacja siatek stalowych i włókna stalowego pozwala na uzyskanie większej sztywność płyty, redukowanie spękań i mikrospękań. Sugeruje się, aby w halach magazynowych projektować i wykonywać płyty bezdylatacyjne, które usprawniają ruch pojazdów transportowych. Jest to bardzo ważny aspekt w przypadku hal wysokiego składowania, gdzie ruch odbywa się po ustalonym torze jazdy, a każda nierówność w posadzce może mieć przełożenie na pracę wysięgnika wózka widłowego na dużej wysokości. Wózki transportowe czy niekiedy samochody ciężarowe poruszające się po hali potrafią znacznie zniszczyć nacięcia płyt posadzkowych i ich wypełnienie. Posadzki betonowe pracują przez cały czas. Niestety ciągła eksploatacja ma negatywny wpływ także na równość (płaskość) płyty betonowej. Płyty betonowe wykonywane w zakładach produkcyjnych są narażone na bardzo intensywną eksploatację prowadzoną w trudnych warunkach. Widoczne na powierzchni betonu plamy, liczne przebarwienia lub miejsca narażone na zwiększoną ścieralność zwykle nie zagrażają nośności posadzki i nie przeszkadzają w prawidłowym jej użytkowaniu, dopóki nie pojawią się głębokie ubytki w ciągach komunikacyjnych. 


\section{PIŚMIENNICTWO}

BS 8204-2:2002. Screeds, bases and in-situ floorings. Concrete wearing surfaces. Code of practice.

Concrete Society (2014). Concrete industrial ground floors - a guide to their design and construction (Technical Report 34). Oxford.

Deręgowska, B. i Szymczak-Graczyk, A. (2017). Ocena przydatności płyt z pianki poliuretanowej, traktowanych jako podłoże sprężyste pod posadzki. Materiały Budowlane, 537 (5), 126-127.

Fidali, R. (2010). Ogólnopolski informator posadzkarski. Sosnowiec: E-Vandor.

Hajduk, P. (2018). Monolityczne podłogi betonowe. Inżynier Budownictwa, 11, 85-88.

Jasiczak, J. (2001). Posadzki przemystowe. Materiaty, technologie, projektowanie, naprawy. Poznań: Addiment Polska Sp. z o.o. i Instytut Konstrukcji Budowlanych Politechniki Poznańskiej.
Małasiewicz, A. i Tejchman, J. (2006). Posadzki przemysłowe. Gdańsk: Wydawnictwo Politechniki Gdańskiej.

Osińska, J. (2017). Analiza posadzek przemysłowych zbrojonych tradycyjnie i za pomocq wtókien (praca magisterska). Politechnika Poznańska, Poznań.

Osińska, J. i Ksit, B. (2017). Analiza współczesnych bezspoinowych posadzek zbrojonych - studium przypadków. W A. Szymczak-Graczyk i B. Ksit (red.), Budownictwo a środowisko problemy architektoniczno-techniczne obiektów budowlanych (strony 175-188). Poznań: ZO PZITB.

Ryżyński, W. i Karczewski, B. (2014). Wyznaczanie parametrów obliczeniowych podłoża warstwowego pod posadzką przemysłową. Nowoczesne Hale, 5, 34-38.

Tehrani, F. M. (2008). Performance of steel fiber-reinforced concrete in beam-column connections. Los Angeles: ProQuest Dissertations Publishing.

\title{
EXAMPLES OF REPAIRS AND THE RENOVATION OF INDUSTRIAL FLOORS
}

\begin{abstract}
Damage to concrete floors concerns their topcoat mainly and it is possible to divide them in a few groups: of crack, breaking off, the loosening, shelling and the change of the equality. The repair system is making a perfect match depending on the scale of becoming dilapidated and laying him (differently repair will be planning for the crack of the floor in the transport lane, and differently by the pole). Supplements are repair basic methods (with elastic mass, with epoxy resin or cement mass) and grinding and polishing. It is very important to properly design all layers of the industrial floor.
\end{abstract}

Key words: industrial floor, repair, renovation, concrete slabs 